\title{
Rapid global ocean-atmosphere response to Southern Ocean freshening during the last glacial
}

Chris S.M. Turney (1) 1,2,3, Richard T. Jones ${ }^{4}$, Steven J. Phipps (1) 2,5, Zoë Thomas (1) 1,2,3, Alan Hogg6 A. Peter Kershaw7, Christopher J. Fogwill (1) 1,2, Jonathan Palmer (1) 1,2,3, Christopher Bronk Ramsey (1) ${ }^{8}$, Florian Adolphi (10) 9,10, Raimund Muscheler ${ }^{9}$, Konrad A. Hughen ${ }^{11}$, Richard A. Staff (1) 8,12, Mark Grosvenor (D) ${ }^{4}$, Nicholas R. Golledge (10) ${ }^{13,14}$, Sune Olander Rasmussen (1) ${ }^{15}$, David K. Hutchinson (1) ${ }^{16}$, Simon Haberle ${ }^{17}$, Andrew Lorrey ${ }^{18}$, Gretel Boswijk (i) ${ }^{19}$ \& Alan Cooper (iD) 20

Contrasting Greenland and Antarctic temperatures during the last glacial period (115,000 to 11,650 years ago) are thought to have been driven by imbalances in the rates of formation of North Atlantic and Antarctic Deep Water (the 'bipolar seesaw'). Here we exploit a bidecadally resolved ${ }^{14} \mathrm{C}$ data set obtained from New Zealand kauri (Agathis australis) to undertake high-precision alignment of key climate data sets spanning iceberg-rafted debris event Heinrich 3 and Greenland Interstadial (GI) 5.1 in the North Atlantic ( 30,400 to 28,400 years ago). We observe no divergence between the kauri and Atlantic marine sediment ${ }^{14} \mathrm{C}$ data sets, implying limited changes in deep water formation. However, a Southern Ocean (Atlantic-sector) iceberg rafted debris event appears to have occurred synchronously with GI-5.1 warming and decreased precipitation over the western equatorial Pacific and Atlantic. An ensemble of transient meltwater simulations shows that Antarctic-sourced salinity anomalies can generate climate changes that are propagated globally via an atmospheric Rossby wave train.

\footnotetext{
${ }^{1}$ Palaeontology, Geobiology and Earth Archives Research Centre, School of Biological, Earth and Environmental Sciences, University of New South Wales, Sydney, NSW 2052, Australia. ${ }^{2}$ Climate Change Research Centre, School of Biological, Earth and Environmental Sciences, University of New South Wales, Sydney, NSW 2052, Australia. ${ }^{3}$ ARC Centre of Excellence in Australian Biodiversity and Heritage, School of Biological, Earth and Environmental Sciences, University of New South Wales, Sydney, NSW 2052, Australia. ${ }^{4}$ Department of Geography, University of Exeter, Exeter, Devon EX4 4RJ, UK. ${ }^{5}$ Institute for Marine and Antarctic Studies, University of Tasmania, Private Bag 129, Hobart, TAS 7001, Australia. ${ }^{6}$ Waikato Radiocarbon Laboratory, University of Waikato, Private Bag 3105, Hamilton 3216, New Zealand. ${ }^{7}$ School of Earth, Atmosphere and Environment, Monash University, VIC 3800 , Australia.

${ }^{8}$ Research Laboratory for Archaeology and the History of Art, University of Oxford, Dyson Perrins Building, South Parks Road, Oxford OX1 3QY, UK.

${ }^{9}$ Department of Geology-Quaternary Sciences, Lund University, 22362 Lund, Sweden. ${ }^{10}$ Climate and Environmental Physics, University of Bern, CH-3012 Bern, Switzerland. ${ }^{11}$ Woods Hole Oceanographic Institution, Woods Hole, MA 02543, USA. ${ }^{12}$ Scottish Universities Environmental Research Centre (SUERC), University of Glasgow, Rankine Avenue, East Kilbride G75 0QF, UK. ${ }^{13}$ Antarctic Research Centre, Victoria University of Wellington, Wellington 6140, New Zealand. ${ }^{14}$ GNS Science, Lower Hutt 5011, New Zealand. ${ }^{15}$ Centre for Ice and Climate, Niels Bohr Institute, University of Copenhagen, Juliane Maries Vej 30 , 2100 Copenhagen, Denmark. ${ }^{16}$ Bolin Centre for Climate Research and Department of Geological Sciences, Stockholm University, 10691 Stockholm, Sweden. ${ }^{17}$ Department of Archaeology and Natural History and ARC Centre of Excellence in Australian Biodiversity and Heritage, College of Asia and the Pacific, Australian National University, Canberra, ACT 2601, Australia. ${ }^{18}$ National Institute of Water and Atmospheric Research Ltd, Auckland 1010, New Zealand. ${ }^{19}$ School of Environment, The University of Auckland, Private Bag 92019, Auckland 1142, New Zealand. 20 Australian Centre for Ancient DNA and ARC Centre of Excellence in Australian Biodiversity and Heritage, School of Biological Sciences, The University of Adelaide, Adelaide, SA 5005, Australia. Correspondence and requests for materials should be addressed to C.S.M.T. (email: c.turney@unsw.edu.au)
} 
D uring the last glacial, the global redistribution of heat is widely considered to be the cause of contrasting temperature trends between the hemispheres via an ocean pathway that operates on centennial timescales (the bipolar seesaw) ${ }^{1-7}$, with abrupt cooling identified in the Greenland ice cores (Greenland Stadials; GS) leading the initiation of warming over Antarctica (Antarctic Isotope Maxima; AIM) ${ }^{4}, 6$. Although oceanic meridional heat transport variations are recorded through most of this period, recent work on North Atlantic marine sediments has highlighted limited changes in ocean circulation between 33 and $18 \mathrm{kyr} \mathrm{BP}^{8-10}$, and yet a pervasive antiphase temperature relationship continues to be observed between Greenland and Antarctica, ${ }^{4}$, implying that additional mechanism (s) may have also operated during the glacial. Whilst atmospheric circulation variability may help to generate anti-phase hemispheric temperatures on monthly to decadal timescales-via latitudinal migration of the Intertropical Convergence Zone (ITCZ) and Southern Hemisphere storm tracks ${ }^{6},{ }^{11}$-the relationship is not consistent during all events ${ }^{12}$. To test whether other mechanisms in addition to the bipolar seesaw may have also

a

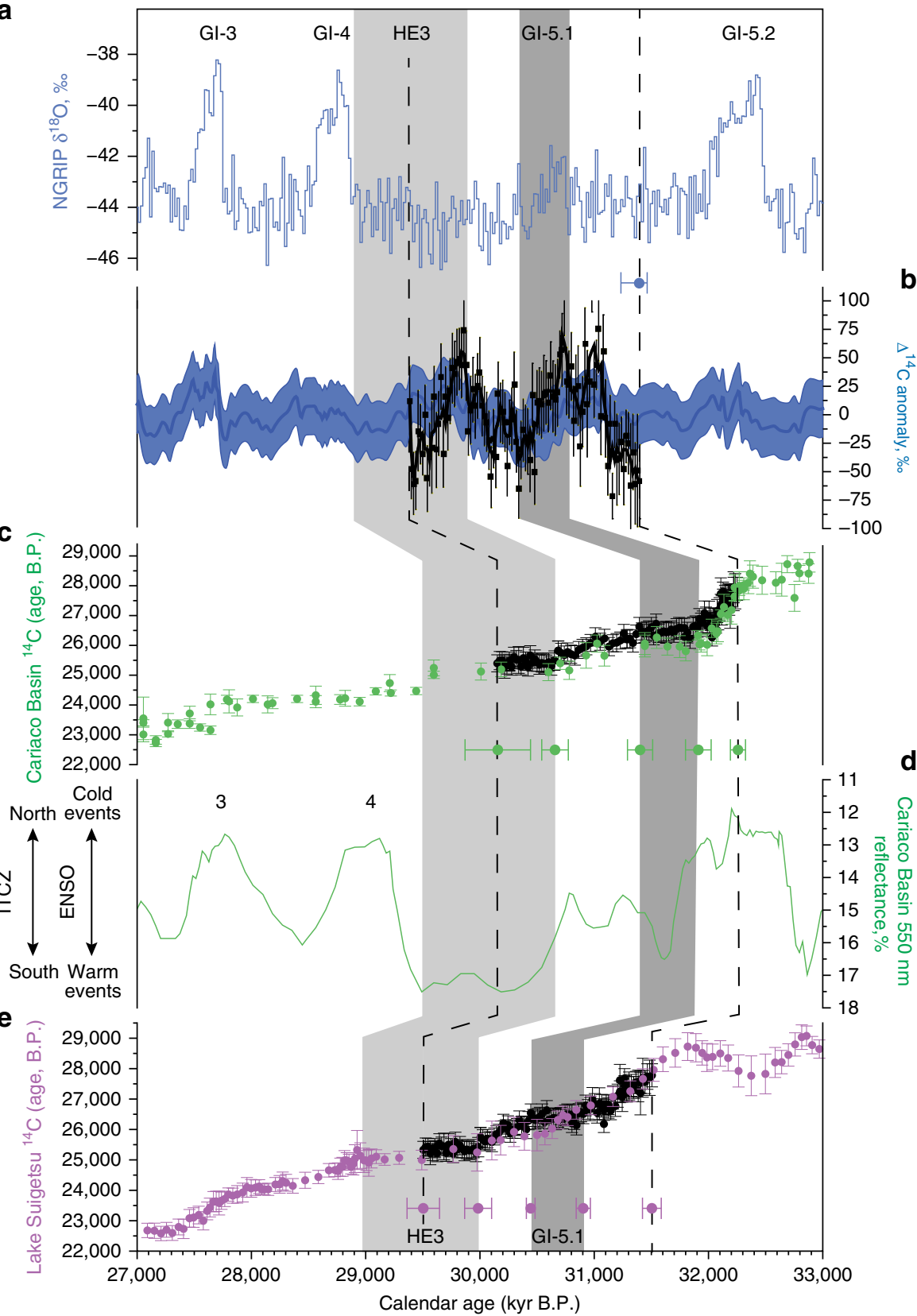

Fig. 1 High-precision alignment of 2000-year long Finlayson 8 kauri tree ${ }^{14} \mathrm{C}$ measurements to key datasets. Bidecadal $\Delta^{14} \mathrm{C}$ data through the kauri tree (black filled circles with 3 point-running mean) compared to the Greenland (blue) $\delta^{18} \mathrm{O}$ and detrended ${ }^{10} \mathrm{Be}$ flux-derived $\Delta^{14} \mathrm{C}$ anomalies ${ }^{10},{ }^{16} \mathbf{a}, \mathbf{b}$. Comparison of kauri ${ }^{14} \mathrm{C}$ age measurements and Cariaco Basin ${ }^{14}$ (c and $\mathbf{d}$; green symbols) and Lake Suigetsu ${ }^{13}$ (e; purple symbols) radiocarbon $\left({ }^{14} \mathrm{C}\right.$ ) calibration data sets on the modelled Hulu Cave and $\mathrm{SGO6}_{2012}$ timescales, respectively. Green reflectance changes preserved in the tropical Atlantic Cariaco Basin marine sequence provide a measure of the meridional migration of the Intertropical Convergence Zone (ITCZ; d). Greenland Interstadials are numbered; Heinrich Event 3 (HE3, based on the climatostratigraphic position in MD95-2040) ${ }^{17}$ and Greenland Interstadial 5.1 (GI-5.1) are shown by light and dark grey columns, respectively. The dashed lines denote the time range captured by the 2000 -year kauri ${ }^{14} \mathrm{C}$ record used in this study ${ }^{10}$. Calendar age uncertainties for synchronization of records shown at $2 \sigma$ (95\% confidence limits) 
a
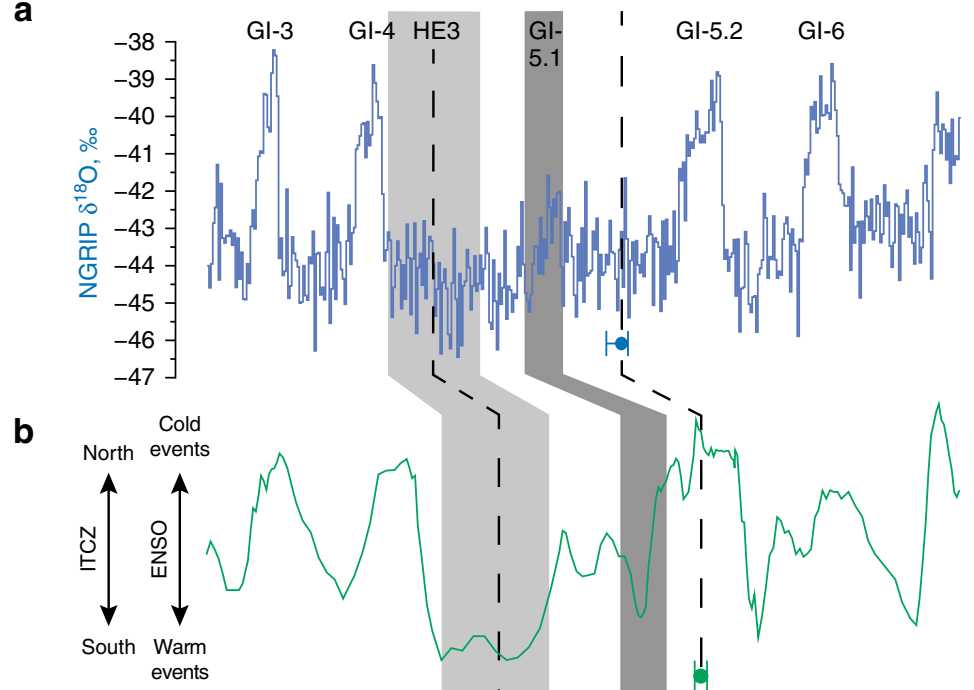

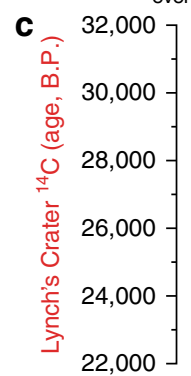

d
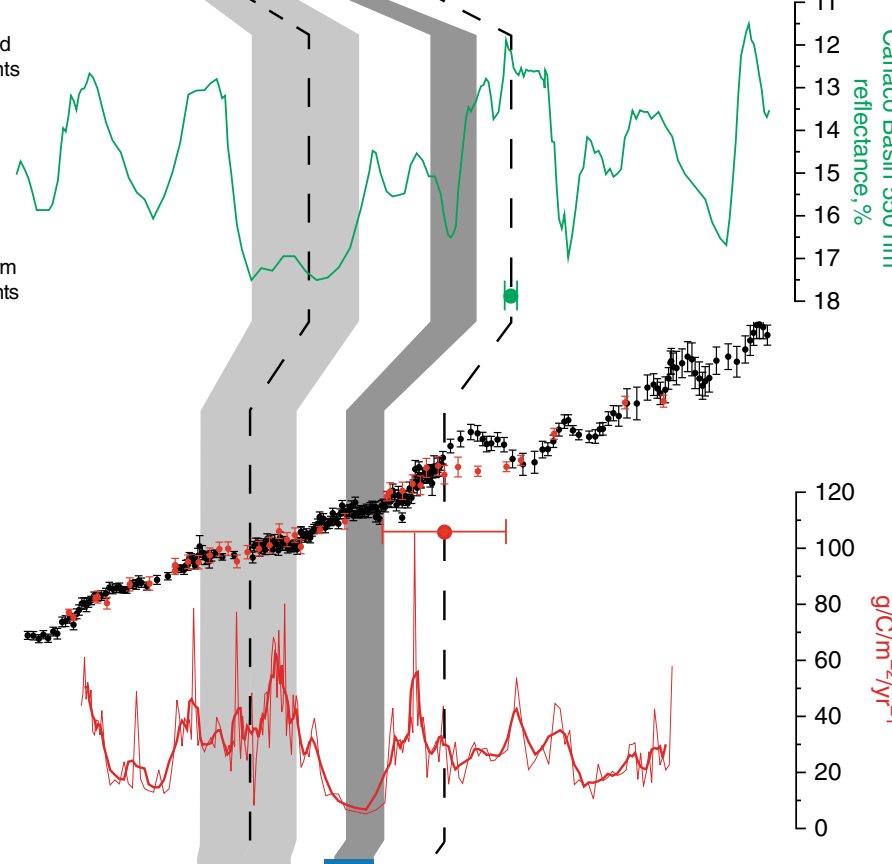

e

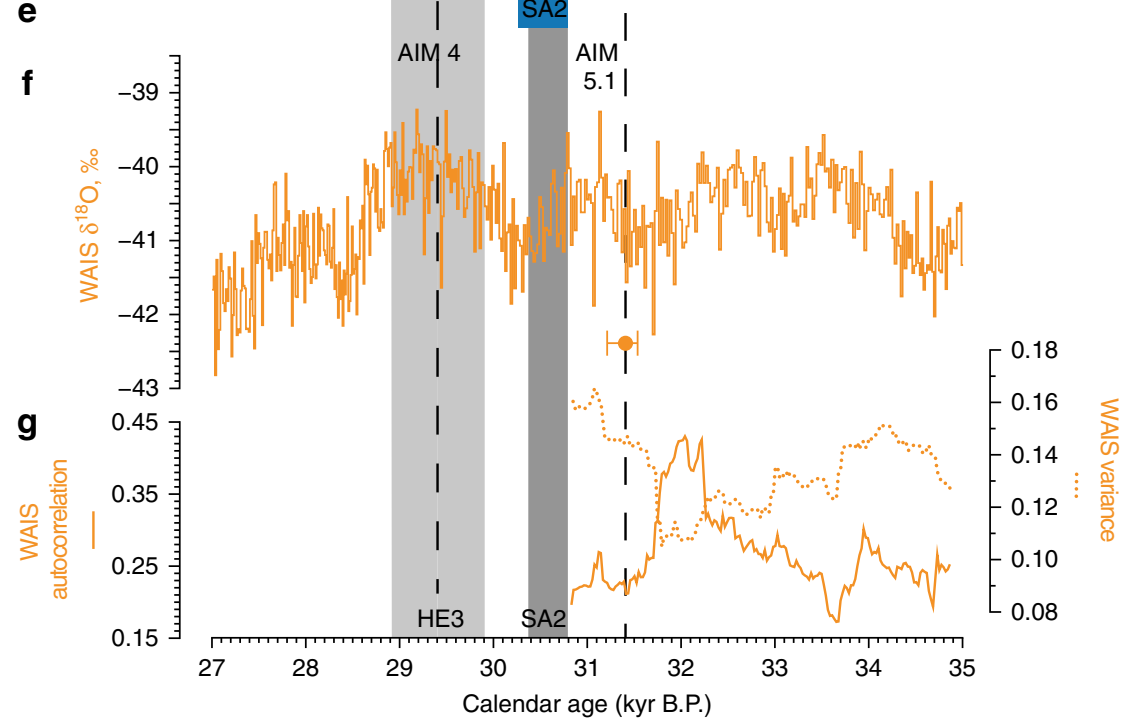

Fig. 2 Global radiocarbon and environmental changes between 35 and 27 kyr BP. Comparison between North Greenland $\delta^{18} \mathrm{O}$ on the GICC05 timescale $\mathbf{a}^{16}$, Cariaco Basin greenscale on the modelled Hulu Cave timescale $\mathbf{b}^{14,33}$, Bayesian wiggle-match of the Lynch's Crater (red) against the kauri-Lake Suigetsu calibration timescale (black) ${ }^{10} ;{ }^{14} \mathrm{C}$ data sets with $1 \sigma$ uncertainties (68\% confidence limits) c, Lynch's Crater carbon flux (red line: 5 -point running mean) d; the climatostratigraphic placement of South Atlantic ice rafted debris layer 2 (SA2) ${ }^{21} \mathbf{e}$; and the West Antarctic Ice Sheet Divide (WAIS) $\delta^{18} \mathrm{O}\left(\right.$ ref. $^{6}$ ) on the WD2014 sync (synchronized to GICC05) timescale (see Methods) f with calculated autocorrelation and variance values $\mathbf{g}$. Greenland interstadials (GI) are numbered above the NGRIP $\delta^{18} \mathrm{O}$ record (a). The positions of Heinrich Event 3 (HE3), Greenland Interstadial 5.1 (GI-5.1) and SA2 in each record are shown as grey columns. The dashed lines denote the time range captured by the 2000 -year kauri ${ }^{14} \mathrm{C}$ record used in this study ${ }^{10}$. Calendar age uncertainties for synchronization of records shown at $2 \sigma$ 
a

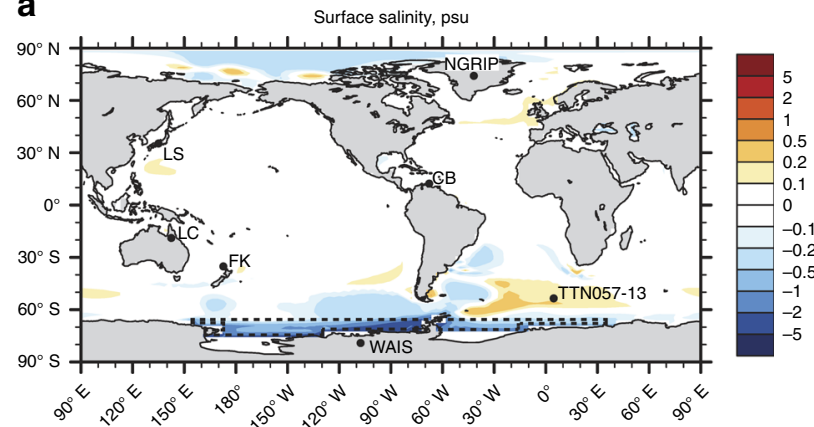

C

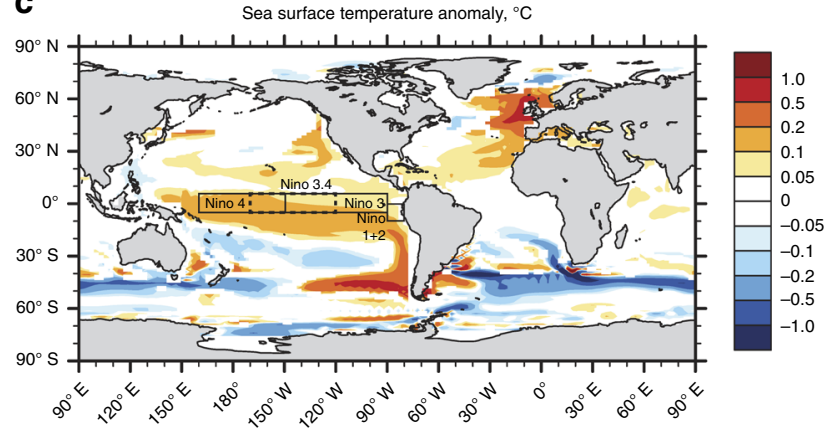

e

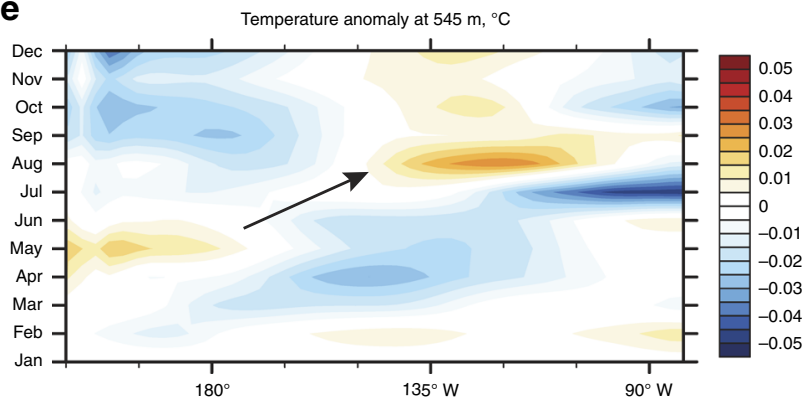

b

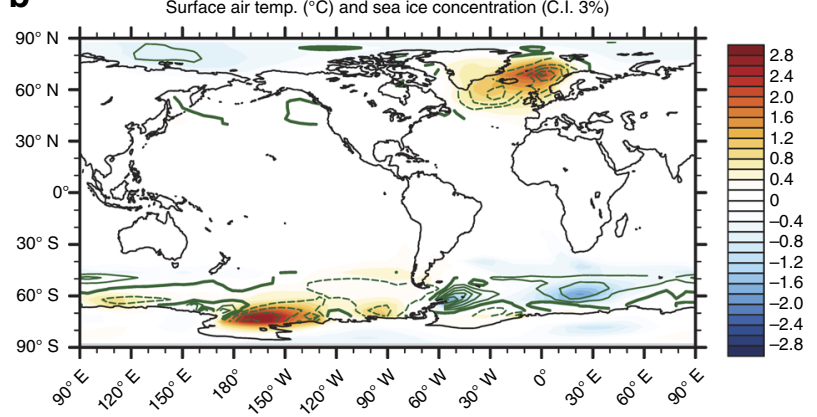

d

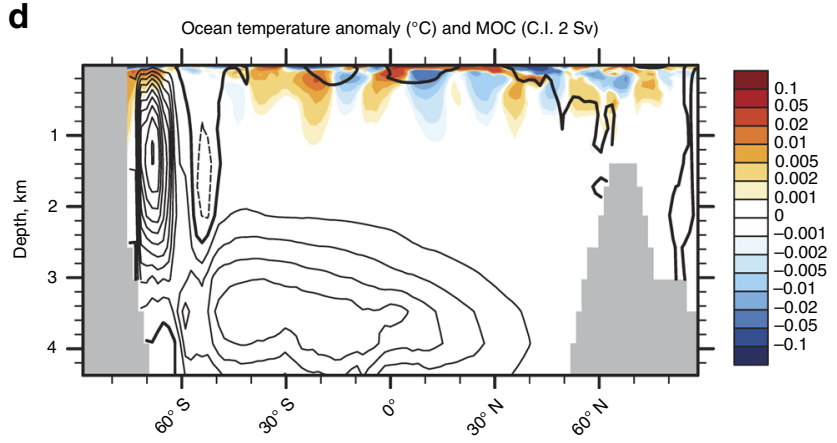

f

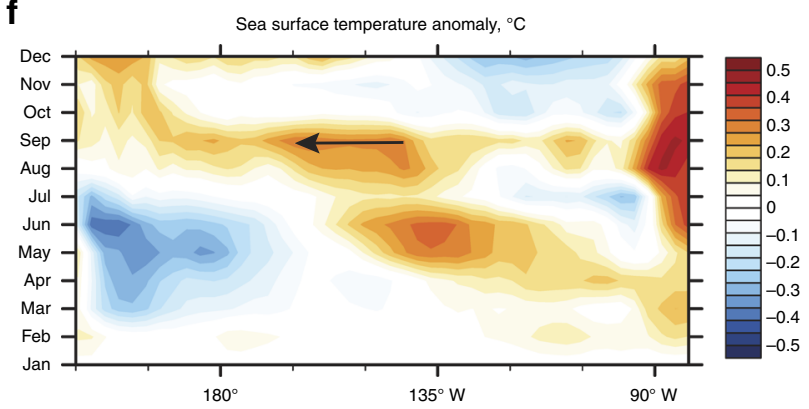

Fig. 3 Summary of CSIRO Mk3L ensemble simulations showing the impact of a 338-year duration freshwater flux of 0.54 Sv into the Weddell and Ross Seas. Salinity anomaly is shown in a (dashed lines denote regions where freshwater applied with key site locations discussed in text shown). Surface air temperature (colour) and sea ice concentration anomalies (green lines; solid = positive, dashed = negative, with a contour interval of $3 \%$ ) seen in $\mathbf{b}$ are not well-correlated with SST anomalies c, but sea ice concentration increases are highly correlated with salinity decreases in the Ross and Amundsen Sea sectors from the freshwater hosing. Global Meridional Overturning Circulation (MOC) anomaly is shown along with ocean temperature anomalies in $\mathbf{d}$, where positive contours are solid, negative contours are dashed and the zero contour is emboldened, with a contour interval of 2 Sverdrups (Sv). The Southern positive cell represents reduced Antarctic Bottom Water (AABW) formation. Anomalies in a-d are averaged over the 338-year duration freshwater flux. Resulting seasonal equatorial $\left(0^{\circ}\right)$ Pacific eastward propagating Kelvin waves at the thermocline during the first year of freshwater application ( $545 \mathrm{~m}$ depth) in $\mathbf{e}$ and westward surface propagating Rossby waves in $\mathbf{f}$ identified by temperature changes. Significance $P<0.05$

operated during the last glacial period requires the precise alignment of ice, marine and terrestrial records, something which hitherto has proved extremely challenging.

Here we exploit a newly-developed bidecadally resolved 2000-year long atmospheric ${ }^{14} \mathrm{C}$ series obtained from a New Zealand sub-fossil kauri tree (Agathis australis) ${ }^{10}$ to quantify time scale differences between key records of the last glacial and explore possible mechanisms to explain global climate patterns across this period.

\section{Results}

Alignment of palaeoclimate records. Bayesian age modelling of the radiocarbon inflections and plateaux preserved in the New Zealand kauri against the tropical Atlantic marine Cariaco Basin and Japanese varved Lake Suigetsu $\left(\mathrm{SG}_{2012}\right)$ records $^{13}, 14$ (see Methods) places the start of tree growth (and associated changes in atmospheric ${ }^{14} \mathrm{C}$ content) on the timescale of these sequences at $32,250 \pm 70 \mathrm{BP}$ and $31,510 \pm 80 \mathrm{BP}$, respectively (Fig. 1). Note, unless ${ }^{14} \mathrm{C}$ is stated, all ages reported here are calendar years relative to $1950 \mathrm{CE}$, Before Present (BP), with $2 \sigma$ uncertainty. We are able to splice the tree ${ }^{14} \mathrm{C}$ record into the Lake Suigetsu sequence providing a refined atmospheric calibration curve and a calendar timescale for calculating radiocarbon concentration $\left(\Delta^{14} \mathrm{C}\right.$; ref. $\left.{ }^{10}\right)$. Cosmogenic radionuclides ${ }^{14} \mathrm{C}$ and ${ }^{10} \mathrm{Be}$ are produced via a nuclear cascade triggered when galactic cosmic rays collide with atmospheric atoms, with changes in the flux of cosmic rays leading to increased (decreased) ${ }^{10} \mathrm{Be}$ and ${ }^{14} \mathrm{C}$ production rates during times of low (high) solar activity and/or geomagnetic field intensity ${ }^{15}$. This offers us a unique opportunity to precisely align the kauri ${ }^{14} \mathrm{C}$ variability with ice core ${ }^{10} \mathrm{Be}$ on the Greenland Ice Core Chronology 2005 (GICC05) ${ }^{10}$. To compare the cosmogenic radionuclides, we modelled $\Delta^{14} \mathrm{C}$ from Greenland ${ }^{10} \mathrm{Be}$ fluxes using a box-diffusion carbon cycle model run under preindustrial conditions ${ }^{15}$. We place the start of the kauri tree-ring series at $31,400^{+70} /_{-160}$ GICC05 BP, covering a 
a

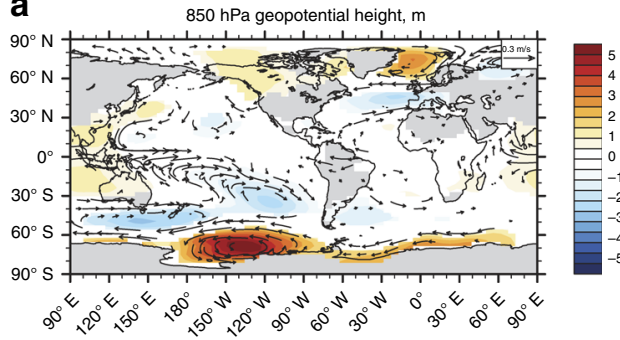

b

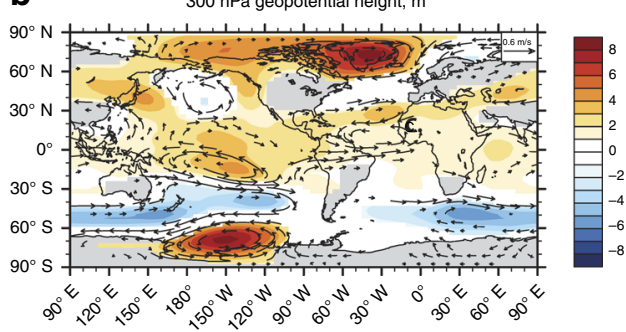

C

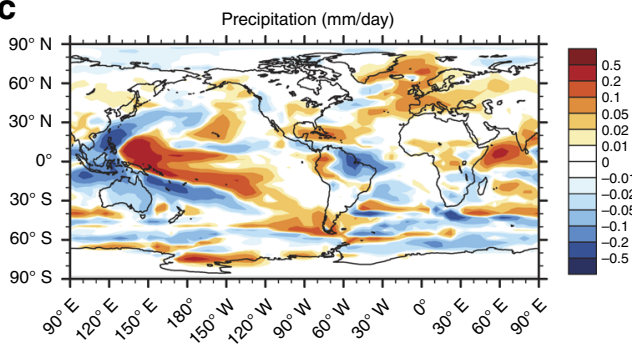

d

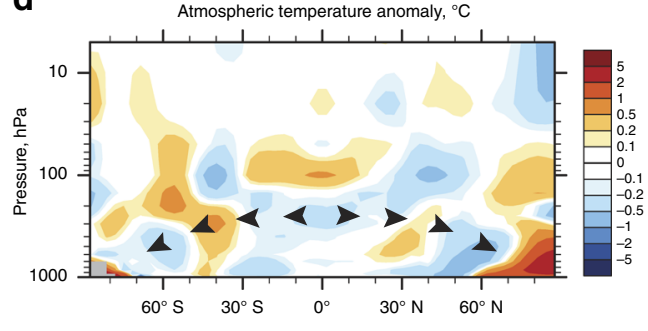

e

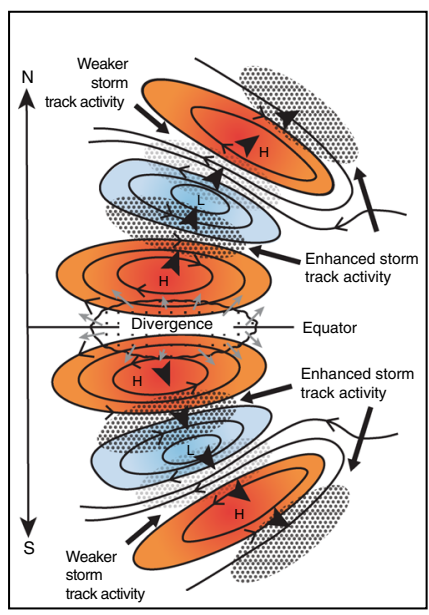

Fig. 4 Modelled global atmospheric propagation of a Southern Ocean freshwater flux during the last glacial period. Geopotential height and wind anomalies at $850 \mathrm{hPa} \mathbf{a} 300 \mathrm{hPa} \mathbf{b}$ and global annual rainfall anomalies c. Zonally averaged global temperature anomalies for the atmosphere $\mathbf{d}$ reflect the characteristic pattern of westerly propagating Rossby waves. a-d produced from CSIRO Mk3L ensemble simulations of a 338-year duration freshwater flux of 0.54 Sv into the Weddell and Ross Seas. The schematic in e shows an idealized extratropical Rossby wave train (solid black arrows) associated with low (blue) and high (red) pressure systems generated by anomalous equatorial Pacific upper-level divergence ${ }^{27,28}$. Significance $P<0.05$

period of time that experienced warming associated with GI-5.1 and North Atlantic iceberg rafted debris layer Heinrich event 3 (IRD HE3; refs 16, 17; Fig. 1 and Supplementary Fig. 1).

To compare global climate changes across the period defined by the kauri we also precisely aligned records from the equatorial west Pacific and Antarctica. We synchronised the West Antarctic Ice Sheet (WAIS) ice core $\delta^{18} \mathrm{O}$ record to Greenland (creating a new timescale: WD2014 $4_{\text {sync }}$, synchronized at GI onsets to GICC05; see Methods). Incorporating the uncertainty associated with time-scale alignment we determine the start of the kauri ${ }^{14} \mathrm{C}$ series in WAIS to be $31,400^{+140} /_{-200} \mathrm{BP}$. We also undertook highresolution analysis of swamp peat sediments preserved in Lynch's Crater, northeastern Australia, a region highly sensitive to changes in moisture-bearing equatorial southeast trade winds in the western equatorial Pacific (Supplementary Fig. 2) ${ }^{18}$. Bayesian age modelling of $44{ }^{14} \mathrm{C}$ ages from the Lynch's Crater sequence allowed us to align it against the combined kauri-Lake Suigetsu radiocarbon curve. We place the onset of the 2000-year period in Lynch's Crater at $31,540 \pm 660 \mathrm{BP}$ (on the $\mathrm{SG}_{06} 6_{2012}$ timescale).

\section{Discussion}

The alignment of ${ }^{14} \mathrm{C}$ and ${ }^{10} \mathrm{Be}$ records allows us to explore global atmospheric and ocean teleconnections across a period of pronounced abrupt climate change (Fig. 2). Here we identify a $\sim 460$-year-long radiocarbon plateau at $\sim 26.4{ }^{14} \mathrm{C}$ kyr BP coincident with GI-5.1 and a $\sim 480$-year duration $\sim 25.4{ }^{14} \mathrm{C}$ kyr BP plateau during a period of enhanced delivery of freshwater and debris-laden icebergs into the North Atlantic associated with HE3 (refs 8, 17, 19; Fig. 1 and Supplementary Fig. 1). The parallel changes in Cariaco Basin surface water (with a mean reservoir age of $372 \pm 35{ }^{14} \mathrm{C}$ years) and atmospheric ${ }^{14} \mathrm{C}$ levels argue against a stratification of surface waters ${ }^{20}$ and collapse of the Meridional Overturning Circulation (MOC) ${ }^{8-10}$ implying the ocean circulation was not appreciably shutdown during the 2000 years captured by our tree-ring series (including during HE3; Fig. 1). Of importance, we find a southward migration of the ITCZ concurrent with the warmth of GI-5.1 (and sustained Antarctic cooling between AIM5.1 and 4), opposite to that anticipated for North Atlantic warming 5 (Fig. 2).

To explore alternative global atmospheric teleconnections, we undertook multi-proxy analyses of the Lynch's Crater sediments. Contiguous carbon analysis allows us to reconstruct changing carbon flux across this period and identifies a $\sim 420$-year downturn that commences at $30,920 \pm 340 \mathrm{BP}$ and coincides with the $\sim 26.4{ }^{14} \mathrm{C}$ kyr BP radiocarbon plateau (Fig. 2). This event is associated with low sediment accumulation rates and low sedge to grass ratios $^{18}$ that both imply relatively dry conditions (Supplementary Fig. 3). We consider this local hydroclimatic response to be a consequence of weakened moisture-laden equatorial Pacific trade winds ${ }^{18}$ which appear to have been synchronous (within the precision of the chronologies reported here) with sustained southward migration of the ITCZ.

Tipping point analysis of the WAIS $\delta^{18} \mathrm{O}$ (WD2014 ${ }_{\text {sync }}$ ) and the Lynch's Crater sequences shows no evidence of critical slowing down in the approach to cooling over the West Antarctic and drying in tropical Australia (which would be manifested as an increase in autocorrelation and variance on the approach to a tipping point) (Fig. 2, and Supplementary Figs. 4 and 5), suggesting that a rapid external climate trigger is more likely to be responsible than a birfurcation associated with slow internal forcing. Although there is no evidence for a weakening of MOC across the period of the radiocarbon plateau at $\sim 26.4{ }^{14} \mathrm{C}$ kyr BP (ref. ${ }^{7-10}$; Fig. 1), a substantial increase in Antarctic ice-sheet discharge occurred immediately prior to the onset of AIM4 evidenced by South Atlantic IRD layer 2 (SA2), south of the Polar Front in South Atlantic marine sequences (e.g., TTN057-13) ${ }^{21}$ (Fig. 2 and Supplementary Fig. 6; see Methods).

To investigate whether a sustained Antarctic ice-sheet drawdown and associated freshwater pulse into the Southern Ocean might explain the observed pattern of global changes we undertook an ensemble of transient meltwater experiments using the fully coupled CSIRO Mk3L global climate system model ${ }^{22}$. For SA2 we applied freshwater fluxes of 0.54 and $0.27 \mathrm{~Sv}$ to the Ross and Weddell Seas for 338 years, comparable to the magnitude and duration of the Last Termination Meltwater Pulse 
1A (MWP-1A $)^{23}$ (see Methods). Following a flux of $0.54 \mathrm{~Sv}$ freshwater, all simulations show surface atmospheric cooling over large parts of the Antarctic continent, with significant surface warming $\left(>1.5^{\circ} \mathrm{C}\right.$ annual mean temperature increase) and decreases (increases) in sea ice extent in the Ross Sea and North Atlantic (South Atlantic) accompanied by pervasive warming in the equatorial Pacific (Fig. 3). Although we find a reduction in the simulated rate of Antarctic Bottom Water (AABW) formation, arising from vertical stratification of the water column in the Ross and Weddell Seas, there is no change in the MOC during our hosing simulations.

Previous modelling studies have implied that Southern Ocean salinity changes can lead to an equatorial and global climate response within a year (refs. ${ }^{24-26}$ ). A key part of this rapid ocean mechanism is the generation of barotropic Kelvin waves that propagate along the Antarctic coastline and are directed north along the western margin of the Pacific Ocean via the South Pacific Rise. The result is excitation of equatorial baroclinic Kelvin waves that leads to pronounced surface warming ${ }^{25}$. Within four months of freshwater hosing in the Ross and Weddell Seas, subsurface temperature anomalies representing eastward travelling baroclinic Kelvin waves appear in our simulations along the equatorial thermocline, crossing the Pacific in approximately three months (Fig. 3e). The arrival of these Kelvin waves in the east Pacific triggers highly non-linear oceanair interactions through the reflection of Rossby waves from the eastern boundary and generation of anomalous westerly equatorial airflow. These waves increase sea surface temperatures $\left(>0.4^{\circ} \mathrm{C}\right.$ ), comparable to previous studies ${ }^{24-26}$ (Fig. 3f).

The model simulations indicate an acute decrease in geopotential height across the mid-latitudes but an increase in the Ross Sea and North Atlantic, the latter coinciding with the location of maximum surface warming (Fig. 4). The warmer equatorial SSTs are associated with deep convection and upper-level divergent flow at $300 \mathrm{hPa}$, forcing what appears to be an atmospheric Rossby wave train in the extratropics, manifested as low pressure anomalies across the mid-latitudes that extend polewards as high pressure anomalies ${ }^{27,28}$ (Fig. 4b). In parallel with these changes we also find marked shifts in equatorial and extra-tropical precipitation with drier conditions in the western Pacific (including northeast Australia) and northern South America, accompanied by wetter conditions over the central Pacific (Fig. 4c). The simulated spatial SST and the precipitation anomaly fields closely resemble the modern (post-1979) global El Niño-like pattern of rainfall change ${ }^{29}$ (Fig. 4 and Supplementary Fig. 8). The increase in Cariaco Basin greenscale that is often interpreted as a measure of southward migration of the ITCZ in response to North Atlantic cooling is consistent with central equatorial Pacific warming associated with El Niño warming, with drier conditions over northern South America ${ }^{30}$ (Fig. 2). The eastward displacement of the convective loci and northeast movement of the South Pacific Convergence Zone seen in the model results is also associated with El Niño events ${ }^{29}$, and is highly relevant to the observed drying at Lynch's Crater. The similarity between proxy time series and 100-year simulation time slices for temperature and precipitation anomalies add further support to this mechanism, with peak warming at the onset of SA2 but persistent drying through the period of freshwater hosing (Supplementary Figs. 9 and 10). Although the impacts of a flux of $0.27 \mathrm{~Sv}$ in the Southern Ocean are smaller than the impacts of a flux of $0.54 \mathrm{~Sv}$, the same trends are observed globally (Supplementary Figs. 11-14), suggesting that this mechanism can operate across a range of freshwater hosing applications.

The similar pattern of observed and modelled temperature, precipitation and sea ice anomalies suggests that coupled Antarctic-Southern Ocean dynamics contributed to some global events through rapid ocean-atmospheric teleconnections. Whilst our findings do not preclude the operation of an ocean bipolar see-saw during other periods within the last glacial, these results provide an additional mechanism for driving past (and future) global change. Although our data and model simulations suggest a remarkably rapid ocean-atmosphere response to Southern Ocean freshening, the relatively muted expression of GI-5.1 implies that this forcing may result in smaller magnitude changes to those driven by the bipolar seesaw. Our findings therefore suggest that contrasting high-latitude temperature trends during the last glacial can also be driven from Antarctica and the Southern Ocean via ocean-atmosphere teleconnections.

\section{Methods}

High-precision alignment of terrestrial and ice records. Multiple trees of different ages across the late Pleistocene were extracted from a swamp on Finlayson Farm $\left(35^{\circ} 83^{\prime} \mathrm{S}, 173^{\circ} 64^{\prime} \mathrm{E}\right.$ ) in 1998 (refs ${ }^{31,32}$ ) from which we have identified a 2000-year long kauri log (henceforth 'Finlayson $8^{\prime}$ ) to generate a bidecadally resolved ${ }^{14} \mathrm{C}$ series to reconstruct atmospheric radiocarbon content ${ }^{10}$. To elucidate changes in atmosphere and ocean circulation across HE3 and GI-5.1, we exploited temporal signals (e.g., using so-called 'radiocarbon plateaux') in two high-

resolution radiocarbon datasets that allow high-precision alignment of the series: a terrestrial record of atmospheric ${ }^{14} \mathrm{C}$ generated from the Japanese varved Lake Suigetsu sequence (using the $\mathrm{SG}_{06} 6_{2012}$ timescale) ${ }^{13}$, and the Venezuelan Cariaco Basin sedimentary sequence, which preserves a record of surface water ${ }^{14} \mathrm{C}$ and changes in the Intertropical Convergence Zone (ITCZ) that parallel Greenland Interstadial events ${ }^{12,14,33}$. The ${ }^{14} \mathrm{C}$ series was calibrated using a Poisson process deposition model (P_Sequence) ${ }^{34}$ with the General Outlier analysis option ${ }^{35}$ in OxCal 4.2. Using Bayes theorem, OxCal identifies possible age solutions for the kauri series of ${ }^{14} \mathrm{C}$ ages in the Cariaco Basin and Lake Suigetsu calibration data sets. To accommodate a possible collapse in the marine reservoir age $(\Delta \mathrm{R})$ through the Cariaco Basin sequence $\left(420{ }^{14} \mathrm{C}\right.$ years $)$, a Delta_R $(\Delta \mathrm{R})$ with the prior $\mathrm{U}(0,420)$ was used, allowing ${ }^{14} \mathrm{C}$ measurements to assume atmospheric values if required. Whilst neither of the ${ }^{14} \mathrm{C}$ calibration datasets applied here are bidecadally resolved across the period spanning HE3 and GI-5.1, there is sufficient structure in both series to precisely align the Finlayson $8{ }^{14} \mathrm{C}$ data set, providing a chronology for the kauri, and in the case of the Cariaco Basin, demonstrating no significant sustained changes in marine reservoir ages across this period ${ }^{10}$

To compare the kauri ${ }^{14} \mathrm{C}$ series with the Greenland Ice Core Chronology 2005 $\left(\right.$ GICC05) ${ }^{16,36,37}$, we aligned variations in atmospheric radiocarbon concentration $\left(\Delta^{14} \mathrm{C}\right)$ as recorded by the New Zealand tree against the ${ }^{10} \mathrm{Be}$ measurements from the GRIP ice core ${ }^{10}, 15,38,39$. We placed the kauri $\Delta^{14} \mathrm{C}$ sequence on the GICC05 chronology using previously reported methods ${ }^{10,40}$. Due to carbon cycle effects the atmospheric $\Delta^{14} \mathrm{C}$ signal was dampened and delayed compared to ${ }^{14} \mathrm{C}$ production rate variations. Hence, we modeled $\Delta^{14} \mathrm{C}$ from GRIP ${ }^{10} \mathrm{Be}$ fluxes assuming these are proportional to global production rate variations using a box-diffusion carbon cycle model run under preindustrial conditions ${ }^{15}, 41$. The long-term trends in $\Delta^{14} \mathrm{C}$ can be increasingly affected by carbon cycle changes which are not reflected in ${ }^{10} \mathrm{Be}$ and difficult to quantify ${ }^{15}, 40$. Due to the radioactive decay of ${ }^{14} \mathrm{C}$ and the relatively old ages of the kauri, ${ }^{14} \mathrm{C}$ measurement uncertainties are too large to resolve the centennial $\Delta^{14} \mathrm{C}$ variations that have been used for ${ }^{10} \mathrm{Be} /{ }^{14} \mathrm{C}$ synchronization by Adolphi and Muscheler (2016) during a more recent period. Hence, we high-pass filtered the ${ }^{10} \mathrm{Be}$-based $\Delta^{14} \mathrm{C}$ record with a cutoff frequency of $1 / 2000$ per year and linearly detrended the kauri $\Delta^{14} \mathrm{C}$ data. Given the length of the kauri chronology of 2000 years, this detrending is comparable to a 2000 -year high pass filter but it avoids edge-effects induced by filtering. It is difficult to estimate an uncertainty to the GRIP ${ }^{10} \mathrm{Be}$-based $\Delta^{14} \mathrm{C}$ record. Uncertainties arising from the unknown history of the carbon cycle as shown by Muscheler et al. ${ }^{15}$ may be systematic (on the time scales considered here), and would be removed by filtering the modelled $\Delta^{14} \mathrm{C}$. On the other hand, a different state of the ocean's deep convection and/or air-sea gas exchange rates would impact on the amplitude of $\Delta^{14} \mathrm{C}$ variations for a given ${ }^{14} \mathrm{C}$ production rate change ${ }^{42}$, which would also be present after filtering. We therefore assigned a $1 \sigma$ uncertainty of $25 \%$ to the GRIP ${ }^{10} \mathrm{Be}$-based $\Delta^{14} \mathrm{C}$ record. This is consistent with simulated millennial $\Delta^{14} \mathrm{C}$ variations that can be induced by carbon cycle changes alone ${ }^{42}$. It should be noted, however, that the derived fits of the kauri sequence onto the modelled $\Delta^{14} \mathrm{C}$ record depend very little in practice on the assumed error for the GRIP ${ }^{10} \mathrm{Be}$-based record. Details regarding the mathematical formulation of the method and its application to ${ }^{14} \mathrm{C}$ and ${ }^{10} \mathrm{Be}$ records have been published elsewhere ${ }^{40,43}$. To take into account the relative uncertainty of the ice core time scale we repeated the calculations assuming linear stretches from -100 to $100 \%$ of the GICC05 maximum counting error in steps of $10 \%$ for the period of overlap.

The Cariaco Basin marine record. The Venezuelan Cariaco Basin marine palaeoclimate record is the $550 \mathrm{~nm}$ reflectance data from ODP Hole 1002C. The age model is based on matching abrupt palaeoclimate shifts between the Cariaco Basin and Hulu Cave speleothem records. The age model is an update on previous 
studies ${ }^{10}, 14,33$ using more highly-resolved Hulu $\delta^{18} \mathrm{O}$ data that allow more precise identification of the timing of Dansgaard-Oeschger (D-O) events used as tie-points. Regardless, the conclusions of this study are insensitive to the chronology used given the green reflectance and ${ }^{14} \mathrm{C}$ data are directly linked. Essentially, these are the palaeoclimate data that accompany the updated Cariaco Basin marine ${ }^{14} \mathrm{C}$ ages used in IntCal1 $3^{44}$.

Ice rafted debris events in marine sediments. The IRD (HE3) and summer SST records from MD95-2040 ${ }^{17}$ were placed on a calibrated timescale using a Poisson process deposition model (P_Sequence) ${ }^{34}$ with the General Outlier analysis option $^{35}$ in OxCal 4.2. Radiocarbon ages were calibrated using the Marine13 calibration data set ${ }^{44}$ and Greenland isotope event boundaries ${ }^{16}$ were imported. To accommodate uncertainties in the marine reservoir age, a Delta_R with the prior $\mathrm{U}$ $(-400,0)$ was used (Supplementary Table 1$)$. A mean $\Delta^{14} \mathrm{C}$ of $278 \pm 90$ years was determined for the sequence (Supplementary Fig. 1). The IRD and planktic $\delta^{18} \mathrm{O}$ data from the South Atlantic (SA2) are based on reported calibrated ages (Supplementary Fig. 6) ${ }^{21}$. Whilst previous work has suggested the IRD is dominated by volcanic ash shard fallout from the South Sandwich Island onto sea ice in the South Atlantic ${ }^{45}$, the parallel increase in quartz grains within this horizon remains consistent with an increased discharge of Antarctic ice ${ }^{46}$.

Lynch's Crater site description. To reconstruct western equatorial Pacific changes across the period spanning HE3 and GI-5.1 we investigated the tropical swamp sequence at Lynch's Crater, northeast Queensland on the Atherton Tableland $\left(17.37^{\circ} \text { S, } 145.69^{\circ} \mathrm{E} \text {; Supplementary Fig. } 2\right)^{18,47-49}$, a site highly sensitive to precipitation changes delivered by moisture-bearing southeast trade winds ${ }^{18}$. The volcanic crater contains around $64 \mathrm{~m}$ of lake and peat sediments, and records substantial sedimentological and palaeoecological change in response to climatic oscillations as well as more sustained changes in plant taxon and community distributions.

\section{Lynch's Crater radiocarbon dating and climate reconstruction. The original} Lynch's Crater chronology was based upon bulk radiocarbon $\left({ }^{14} \mathrm{C}\right)$ ages derived from the uppermost $16 \mathrm{~m}$ of the sequence, assuming linear accumulation and taking into account the moisture content of the peat ${ }^{50}$. Using a Livingstone cored sequence obtained in 1998 , we undertook comprehensive ${ }^{14} \mathrm{C}$ sampling (44 peat samples) between 4 and $7 \mathrm{~m}$, with most of the ages focused on 4.9 to $6.95 \mathrm{~m}$ (spanning the period of accumulation that includes SA2). Bulk samples were pretreated using an acid-base-acid (ABA) protocol (with multiple base extractions) and then combusted and graphitized in the University of Waikato AMS laboratory, with ${ }^{14} \mathrm{C} /{ }^{12} \mathrm{C}$ measurement by the University of California at Irvine (UCI) on a NEC compact (1.5SDH) AMS system. The pretreated samples were converted to $\mathrm{CO}_{2}$ by combustion in sealed pre-baked quartz tubes, containing $\mathrm{Cu}$ and $\mathrm{Ag}$ wire. The $\mathrm{CO}_{2}$ was then converted to graphite using $\mathrm{H}_{2}$ and a Fe catalyst, and loaded into aluminium target holders for measurement at UCI. Samples of ABApretreated Waikato OIS7 kauri background standard ${ }^{51}$ were prepared and measured with the unknown age samples. Results on the OIS7 blank ranged from 0.0008 to $0.0015 \mathrm{~F}^{14} \mathrm{C}(57.2-52.4 \mathrm{kyr} \mathrm{BP})$ with a mean of $0.0012 \mathrm{~F}^{14} \mathrm{C}(53.8 \mathrm{kyr}$ $\mathrm{BP}$ ), with an assumed uncertainty of $\pm 30 \%$. The quoted uncertainties are compiled from uncertainties in the Background and Modern standards, as well as from the variability in the repeated runs on each sample and from counting statistics. The radiocarbon ages were calibrated against the new combined kauri-Lake Suigetsu calibration dataset ${ }^{10}$ using a $\mathrm{P}$ ssequence deposition model with the General Outlier analysis option in OxCal $4.2^{3 \overline{4}, 35}$ (Supplementary Software 1). The resulting age model generated an Agreement Index of $170.2 \%\left(A_{\text {overall }}=161.4\right.$; Supplementary Table 2), exceeding the recommended $>60 \%{ }^{52}$.

In parallel with the comprehensive dating, we undertook high-resolution Total Organic Carbon (\%TOC) analysis of the peat sediments straddling the time of SA2. Contiguous $1 \mathrm{~cm}$ samples were taken between 5 and $7 \mathrm{~m}$ and measured for TOC, determined using a LECO TruSpec CN analyser at the University of New South Wales Analytical Centre following standard techniques ${ }^{53}$. The high-resolution dating allowed us to reconstruct changes in the carbon flux (the amount of carbon sequestered) at Lynch's Crater using previously reported methods ${ }^{54}$. The sustained decrease in carbon flux and associated drying is consistent with other records elsewhere on the Atherton Tableland, including a contemporaneous layer of gypsum $\left(\mathrm{CaSO}_{4}\right)$ representing a significant moisture deficit in Strenekoff's Crater ${ }^{55}$, approximately $5 \mathrm{~km}$ from Lynch's Crater.

West Antarctic ice sheet alignment. The original West Antarctic Ice Sheet (WAIS) Divide deep ice core WD2014 chronology was constructed through a combination of annual-layer counting (0-31.2 kyr BP) and interpolar methane synchronisation $(31.2-68 \mathrm{kyr} \mathrm{BP})^{56,57}$. The period of interest here lies exactly in this transition zone. Therefore, we used an alternative WAIS Divide chronology for the $2700-2850 \mathrm{~m}$ depth range $\left(27-31.2 \mathrm{kyr}\right.$ BP), called WD2014 syno $_{\text {, in which }}$ the methane synchronization method ${ }^{56}$ is extended to include DO events 3 through 5.1 (Supplementary Data 1). Note that in the original chronology this depth range was dated using annual-layer counting. The methods and uncertainty estimation in the new WD2014 $4_{\text {sync }}$ chronology follow those described in Buizert et $\mathrm{al}^{56}$
Tipping point analysis. Tipping point analysis was undertaken to test whether changes in the Lynch's Crater carbon sequestration rate and the West Antarctic Ice Sheet (WAIS) Divide $\delta^{18} \mathrm{O}$ (WD2014 $4_{\text {sync }}$ ) might have been a result of long-term forcing. Here statistical properties of the data were analysed to see whether signals of 'critical slowing down' can be detected ${ }^{58-60}$. Critical slowing down occurs when a system approaches a bifurcation, characterised by a decreasing recovery rate to small perturbations. This can be detected as a short-term increase in the lag-1 autocorrelation of the time series ${ }^{61}$, often also accompanied by an increase in variance $^{59}$. However, bifurcational tipping is just one subset in the group of tipping points ${ }^{62}$; noise-induced tipping points are not caused by a slow internal forcing, and are rather forced by an external trigger. The detection of critical slowing down in the case of a noise-induced tipping would therefore not be expected. To test for the presence of critical slowing down, data pre-processing was necessary before the autocorrelation and variance could be measured. This included detrending to remove long-term trends using the Gaussian kernel smoothing function, applied over a suitable smoothing bandwidth, and interpolation to provide equidistant data points. Autocorrelation and variance were then measured over a sliding window ${ }^{59}$ on the resulting residual data after smoothing. The Kendall tau rank correlation coefficient was then applied to provide a quantitative measure of the trend. This metric varies between +1 and -1 , where higher values indicate a stronger increasing trend due to a greater concordance of pairs. Since there are trade-offs in the choice of size of smoothing bandwidth and sliding window of analysis, a sensitivity analysis was undertaken by varying the size of these parameters. The Kendall tau values are then displayed in a contour plot to show how the different parameter choices affect the analysis. Consistent Kendall tau values in the contour plot indicate that the analysis is not sensitive to the parameter choices.

Similar results to the WAIS $\delta^{18} \mathrm{O}$ record ${ }^{6}$ (WD2014 $4_{\text {sync }}$ ) were obtained for tipping point analysis of the carbon accumulation data from Lynch's Crater during the shift to drier conditions in tropical Australia (Fig. 2, and Supplementary Figs. 4 and 5). A slight increasing trend in variance is found in the WAIS data (though not the Lynch's Crater record), which may suggest that the system was becoming noisier. However, it must be acknowledged that due to the challenges in identifying false positives and false negatives ${ }^{60}$, particularly in sparsely sampled palaeoclimate data ${ }^{60}$, these results cannot be considered conclusive, but are suggestive of a lack of bifurcation, consistent with a single forced event.

Modelling the impact of a Southern Ocean freshwater pulse. Our simulations used the Commonwealth Scientific and Industrial Research Organisation Mark version $3 \mathrm{~L}$ (CSIRO Mk3L) climate system model version 1.2, comprising fully interactive ocean, atmosphere, land and sea ice sub-models ${ }^{22,} 63,64$. CSIRO Mk3L employs a reduced horizontal resolution and is designed for millennial-scale climate simulations. The ocean model is a 'rigid lid' model (i.e., the surface is fixed), with a horizontal resolution of $1.6^{\circ}$ latitude $\times 2.8^{\circ}$ longitude and 21 vertical levels, while the atmosphere model has a horizontal resolution of $3.2^{\circ}$ latitude $\times 5.6^{\circ}$ longitude and 18 vertical levels. A smoothed version of the 2-Minute Gridded Global Relief Data (ETOPO2v2) topography (https://www.ngdc.noaa.gov/mgg/ global/etopo2.html) was used for the simulations (Supplementary Fig. 7). Despite the reduced horizontal resolution, the model has a stable and realistic control climatology and has demonstrated utility for simulating the past, present and future evolution of the climate system ${ }^{63-65}$

In this study, an ensemble modelling approach was employed in which each experiment was repeated three times. Three experiments were conducted. In the first experiment, the model was used to conduct a transient simulation of the background climate during the period 32 to $28 \mathrm{kyr} \mathrm{BP}$, in the absence of any catastrophic freshwater fluxes. Each of the three ensemble members was initialized from a different year of a pre-industrial control simulation. Transient changes in the Earth's orbital parameters and greenhouse gas concentrations were imposed (Supplementary Table 3). Land ice was fixed at its extent $21 \mathrm{kyr}$ BP, using the ICE-5G version 1.2 reconstruction ${ }^{66}$.

In the second and third experiments, we simulated a SA2-like event by introducing $0.54 \mathrm{~Sv}$ and $0.27 \mathrm{~Sv}$ of freshwater into the Weddell and Ross Seas over a period of 338 years, comparable to the duration of Meltwater Pulse 1A (MWP-1A) during the Last Termination ${ }^{23,67}$. The $0.54 \mathrm{~Sv}$ flux is equivalent to an increase of $16 \mathrm{~m}$ in global sea level, and was chosen assuming Antarctica was the single source of the upper limit of reconstructed changes in sea level rise across AIM $4^{68}$. Thus, the second experiment was identical to the first, except for a 338 -year duration freshwater flux of $0.54 \mathrm{~Sv}$ beginning at $29.5 \mathrm{kyr}$ BP consistent with reconstructed glacial meltwater discharge for MWP- $1 \mathrm{~A}^{23}$ and imposed over the Weddell and Ross Seas, locations indicated by the Parallel Ice Sheet Model (PISM) for this same event ${ }^{69}$. The third experiment was identical to the second, but used a $0.27 \mathrm{~Sv}$ flux to test whether the mechanism identified with the $0.54 \mathrm{~Sv}$ was also observed using a smaller freshwater hosing (Supplementary Figs. 11 and 12). $29.5 \mathrm{kyr} \mathrm{BP}$ was selected as the period for freshwater hosing application to minimize the effect of changing greenhouse gas forcing. Importantly, our results and those reported elsewhere suggest the magnitude of the forcing to be linearly scaled with freshwater forcing ${ }^{24,25}$ (see also Extended Data Fig. 4 in ref. ${ }^{70}$ ). Each ensemble member was branched off the equivalent ensemble member from the first experiment. 
Data availability. All the new data are provided in Supplementary Information and have also been lodged with the NOAA/World Data Center for Paleoclimatology at https://www.ncdc.noaa.gov/paleo/study/22391.

Received: 7 March 2017 Accepted: 7 July 2017

Published online: 12 September 2017

\section{References}

1. Broecker, W. S. Paleocean circulation during the last deglaciation: a bipolar seesaw? Paleoceanography. 13, 119-121 (1998).

2. Mix, A. C., Ruddiman, W. F. \& McIntyre, A. Late Quaternary paleoceanography of the Tropical Atlantic, 1: Spatial variability of annual mean sea-surface temperatures, 0-20,000 years BP. Paleoceanography. 1, 43-66 (1986).

3. Stocker, T. \& Johnsen, S. A minimum thermodynamic model for the bipolar seesaw. Paleoceanography. 18, 1087 (2003).

4. EPICA Community Members. One-to-one coupling of glacial climate variability in Greenland and Antarctica. Nature. 444, 195-198 (2006).

5. Kageyama, M. et al. Climatic impacts of fresh water hosing under Last Glacial Maximum conditions: a multi-model study. Clim. Past 9, 935-953 (2013).

6. WAIS Divide Project Members. Precise interpolar phasing of abrupt climate change during the last ice age. Nature. 520, 661-665 (2015).

7. Henry, L. et al. North Atlantic ocean circulation and abrupt climate change during the last glaciation. Science 353, 470-474 (2016).

8. Lynch-Stieglitz, J. et al. Muted change in Atlantic overturning circulation over some glacial-aged Heinrich events. Nat. Geosci. 7, 144-150 (2014).

9. Parker, A. O., Schmidt, M. W. \& Chang, P. Tropical North Atlantic subsurface warming events as a fingerprint for AMOC variability during Marine Isotope Stage 3. Paleoceanography, 30, 1425-1436 (2015).

10. Turney, C. S. M. et al. High-precision dating and correlation of ice, marine and terrestrial sequences spanning Heinrich Event 3: Testing mechanisms of interhemispheric change using New Zealand ancient kauri (Agathis australis). Quatern. Sci. Rev. 137, 126-134 (2016).

11. Markle, B. R. et al. Global atmospheric teleconnections during DansgaardOeschger events. Nat. Geosci. 10, 36-40 (2017).

12. Cooper, A. et al. Abrupt warming events drove Late Pleistocene Holarctic megafaunal turnover. Science 349, 602-606 (2015).

13. Bronk Ramsey, C. et al. A complete terrestrial radiocarbon record for 11.2 to 52.8 kyr B.P. Science 338, 370-374 (2012).

14. Hughen, K. A., Southon, J., Lehman, S., Bertrand, C. \& Turnbull, J. Marinederived ${ }^{14} \mathrm{C}$ calibration and activity record for the past 50,000 years updated from the Cariaco Basin. Quatern. Sci. Rev. 25, 3216-3227 (2006).

15. Muscheler, R. et al. Changes in the carbon cycle during the last deglaciation as indicated by the comparison of ${ }^{10} \mathrm{Be}$ and ${ }^{14} \mathrm{C}$ records. Earth. Planet. Sci. Lett. 219, 325-340 (2004).

16. Rasmussen, S. O. et al. A stratigraphic framework for abrupt climatic changes during the Last Glacial period based on three synchronized Greenland ice-core records: refining and extending the INTIMATE event stratigraphy. Quatern. Sci. Rev. 106, 14-28 (2014).

17. de Abreu, L., Shackleton, N. J., Schönfeld, J., Hall, M. \& Chapman, M. Millennial-scale oceanic climate variability off the Western Iberian margin during the last two glacial periods. Mar. Geol. 196, 1-20 (2003).

18. Turney, C. S. M. et al. Millennial and orbital variations of El Niño/Southern Oscillation and high-latitude climate in the last glacial period. Nature. 428, 306-310 (2004).

19. Barker, S. et al. Icebergs not the trigger for North Atlantic cold events. Nature. 520, 333-336 (2015).

20. Hogg, A. et al. Punctuated shutdown of atlantic meridional overturning circulation during the Greenland Stadial 1. Sci. Rep. 6, 25902 (2016).

21. Kanfoush, S. L. et al. Millennial-scale instability of the Antarctic Ice Sheet during the last glaciation. Science 288, 1815-1818 (2000).

22. Phipps, S. J. et al. The CSIRO Mk3L climate system model version 1.0 - Part 1 : Description and evaluation. Geosci. Model Dev. 4, 483-509 (2011).

23. Deschamps, P. et al. Ice-sheet collapse and sea-level rise at the Bølling warming 14,600 years ago. Nature. 483, 559-564 (2012).

24. Richardson, G., Wadley, M. R., Heywood, K. J., Stevens, D. P. \& Banks, H. T. Short-term climate response to a freshwater pulse in the Southern Ocean. Geophys. Res. Lett. 32, L03702 (2005).

25. Blaker, A. T., Sinha, B., Ivchenko, V. O., Wells, N. C. \& Zalesny, V. B. Identifying the roles of the ocean and atmosphere in creating a rapid equatorial response to a Southern Ocean anomaly. Geophysical Research Letters 33, L06720, doi:10.1029/2005GL025474 (2006).

26. Atkinson, C. P., Wells, N. C., Blaker, A. T., Sinha, B. \& Ivchenko, V. O. Rapid ocean wave teleconnections linking Antarctic salinity anomalies to the equatorial ocean-atmosphere system. Geophys. Res. Lett. 36, L08603, doi:10.1029/2008GL036976 (2009).
27. Trenberth, K. E. et al. Progress during TOGA in understanding and modeling global teleconnections associated with tropical sea surface temperatures. J. Geophys. Res. Oceans 103, 14291-14324 (1998).

28. Turney, C. S. M. et al. Tropical forcing of increased Southern Ocean climate variability revealed by a 140 -year subantarctic temperature reconstruction. Clim. Past 13, 231-248 (2017).

29. Dai, A. \& Wigley, T. M. L. Global patterns of ENSO-induced precipitation. Geophys. Res. Lett. 27, 1283-1286 (2000)

30. Haug, G. H., Hughen, K. A., Sigman, D. M., Peterson, L. C. \& Röhl, U. Southward migration of the intertropical convergence zone. Science 293, 1304-1308 (2001).

31. Palmer, J., Turney, C. S. M., Hogg, A. G., Lorrey, A. M. \& Jones, R. J. Progress in refining the global radiocarbon calibration curve using New Zealand kauri (Agathis australis) tree-ring series from Oxygen Isotope Stage 3. Quatern. Geochronol. 27, 158-163 (2015).

32. Turney, C. S. M. et al. Using New Zealand kauri (Agathis australis) to test the synchronicity of abrupt climate change during the Last Glacial Interval (60,000-11,700 years ago). Quatern. Sci. Rev. 29, 3677-3682 (2010).

33. Heaton, T. J., Bard, E. \& Hughen, K. Elastic tie-pointing-transferring chronologies between records via a Gaussian process. Radiocarbon. 55, 1975-1997 (2013).

34. Bronk Ramsey, C. \& Lee, S. Recent and planned developments of the program OxCal. Radiocarbon. 55, 720-730 (2013).

35. Bronk Ramsey, C. Dealing with outliers and offsets in radiocarbon dating. Radiocarbon. 51, 1023-1045 (2009).

36. Rasmussen, S. O. et al. A new Greenland ice core chronology for the last glacial termination. J. Geophys. Res. 111, D06102, doi:10.1029/2005JD006079 (2006).

37. Svensson, A. et al. A 60000 year Greenland stratigraphic ice core chronology. Clim. Past 4, 47-57 (2008).

38. Wagner, G. et al. Presence of the solar de vries cycle ( 205 years) during the last ice age. Geophys. Res. Lett. 28, 303-306 (2001).

39. Yiou, F. et al. Beryllium 10 in the greenland ice core project ice core at summit, greenland. J. Geophys. Res. 102, 26783 (1997).

40. Adolphi, F. \& Muscheler, R. Synchronizing the Greenland ice core and radiocarbon timescales over the Holocene-Bayesian wiggle-matching of cosmogenic radionuclide records. Clim. Past 12, 15-30 (2016).

41. Siegenthaler, U., Heimann, M. \& Oeschger, H. ${ }^{14} \mathrm{C}$ variations caused by changes in the global carbon-cycle. Radiocarbon. 22, 177-191 (1980).

42. Köhler, P., Muscheler, R. \& Fischer, H. A model-based interpretation of lowfrequency changes in the carbon cycle during the last 120,000 years and its implications for the reconstruction of atmospheric $\Delta^{14} \mathrm{C}$. Geochem. Geophys. Geosyst. 7, Q11N06 (2006).

43. Bronk-Ramsey, C., van der Plicht, J. \& Weninger, B. 'Wiggle matching' radiocarbon dates. Radiocarbon. 43, 381-389 (2001).

44. Reimer, P. J. et al. IntCal13 and Marine13 radiocarbon age calibration curves 0-50,000 years cal BP. Radiocarbon. 55, 1869-1887 (2013).

45. Nielsen, S. H. H., Hodell, D. A., Kamenov, G., Guilderson, T. \& Perfit, M. R. Origin and significance of ice-rafted detritus in the Atlantic sector of the Southern Ocean. Geochem. Geophys. Geosyst. 8, Q12005, doi:10.1029/2007GC001618 (2007).

46. Kanfoush, S. Correlation of ice-rafted detritus in South Atlantic sediments with climate proxies in polar ice over the last glacial period. Int. J. Ocean Clim. Syst. 4, 1-20 (2013).

47. Kershaw, A. P. A long continuous pollen sequence from north-eastern Australia. Nature. 251, 222-223 (1974).

48. Kershaw, A. P. A late Pleistocene and Holocene pollen diagram from Lynch's Crater, north-eastern Queensland, Australia. New Phytol. 77, 469-498 (1976).

49. Kershaw, A. P. Record of last interglacial-glacial cycle from northeastern Queensland. Nature. 272, 159-161 (1978).

50. Turney, C. S. M. et al. Development of a robust ${ }^{14} \mathrm{C}$ chronology for Lynch's Crater (North Queensland, Australia) using different pretreatment strategies. Radiocarbon. 43, 45-54 (2001).

51. Hogg, A. G. et al. Dating ancient wood by high sensitivity Liquid Scintillation Spectroscopy and Accelerator Mass Spectrometry - Pushing the boundaries. Quatern. Geochronol. 1, 241-248 (2006).

52. Bronk Ramsey, C. Deposition models for chronological records. Quatern. Sci. Rev. 27, 42-60 (2007).

53. Harris, D., Horwáth, W. R. \& van Kessel, C. Acid fumigation of soils to remove carbonates prior to total organic carbon or carbon-13 isotopic analysis. Soil Sci. Soc. Am. J. 65, 1853-1856 (2001).

54. Yu, Z. et al. Carbon sequestration in western Canadian peat highly sensitive to Holocene wet-dry climate cycles at millennial timescales. Holocene 13, 801-808 (2003).

55. Kershaw, A. P. Pleistocene vegetation of the humid tropics of northeastern Queensland, Australia. Palaeogeogr. Palaeoclimatol. Palaeoecol. 109, 399-412 (1994).

56. Buizert, C. et al. The WAIS Divide deep ice core WD2014 chronology; Part 1: Methane synchronization (68-31 ka BP) and the gas age-ice age difference. Clim. Past 11, 153-173 (2015). 
57. Sigl, M. et al. The WAIS Divide deep ice core WD2014 chronology-Part 2: Annual-layer counting (0-31 ka BP). Clim. Past 12, 769-786 (2016).

58. Dakos, V. et al. Slowing down as an early warning signal for abrupt climate change. Proc. Natl Acad. Sci. USA 105, 14308-14312 (2008).

59. Lenton, T. M., Livina, V. N., Dakos, V., van Nes, E. H. \& Scheffer, M. Early warning of climate tipping points from critical slowing down: comparing methods to improve robustness. Philos. Transac. R. Soc. A Math. Phys. Eng. Sci. 370, 1185-1204 (2012).

60. Thomas, Z. A. Using natural archives to detect climate and environmental tipping points in the Earth System. Quatern. Sci. Rev. 152, 60-71 (2016).

61. Ives, A. R. Measuring resilience in stochastic systems. Ecol. Monogr. 65, 217-233 (1995)

62. Ashwin, P., Wieczorek, S., Vitolo, R. \& Cox, P. Tipping points in open systems: bifurcation, noise-induced and rate-dependent examples in the climate system. Philos. Transac. A 370, 1166-1184 (2012).

63. Phipps, S. J. et al. The CSIRO Mk3L climate system model version 1.0-Part 2: Response to external forcings. Geosci. Model Dev. 5, 649-682 (2012).

64. Phipps, S. et al. Palaeoclimate data-model comparison and the role of climate forcings over the past 1500 years. J. Clim. 26, 6915-6936 (2013).

65. Turney, C. S. M. et al. Obliquity-driven expansion of North Atlantic sea ice during the last glacial. Geophys. Res. Lett. 42, 10382-10390 (2015).

66. Peltier, W. R. Global glacial isostasy and the surface of the ice-age Earth: The ICE-5G (VM2) Model and GRACE. Annu. Rev. Earth. Planet. Sci. 32, 111-149 (2004).

67. Hanebuth, T., Stattegger, K. \& Grootes, P. M. Rapid flooding of the Sunda Shelf: a Late-Glacial sea-level record. Science 288, 1033-1035 (2000).

68. Siddall, M. et al. Sea-level fluctuations during the last glacial cycle. Nature. 423, 853-858 (2003).

69. Golledge, N. R. et al. Antarctic contribution to Meltwater Pulse 1A from reduced Southern Ocean overturning. Nat. Commun. 5, 5107 (2014).

70. Bakker, P., Clark, P. U., Golledge, N. R., Schmittner, A. \& Weber, M. E. Centennial-scale Holocene climate variations amplified by Antarctic Ice Sheet discharge. Nature. 541, 72-76 (2017).

\section{Acknowledgements}

This work was funded by the Australian Research Council (FL100100195, DP170104665 and SR140300001) and the Natural Environment Research Council (NE/H009922/1 and
NE/H007865/1). We thank Dr Charlotte Cook and Dr Sarah Kelloway for helping to process the Lynch's Crater samples, and Dr Christo Buizert for calculating the WD2014 sync chronology.

\section{Author contributions}

C.T. and R.J. conceived the research; C.T., R.J., S.P., Z.T., A.H., J.P., C.B.R., R.S., F.A., R.M. designed the methods and performed the analysis; C.T. wrote the paper with input from R.J., S.P., Z.T., A.H., P.K., C.J.F., J.P., C.B.R., F.A., R.M., K.H., R.S., M.G., N.G., S.R D.H., S.H., A.L., G.B. and A.C.

\section{Additional information}

Supplementary Information accompanies this paper at doi:10.1038/s41467-017-00577-6

Competing interests: The authors declare no competing financial interests.

Reprints and permission information is available online at http://npg.nature.com/ reprintsandpermissions/

Publisher's note: Springer Nature remains neutral with regard to jurisdictional claims in published maps and institutional affiliations.

\section{(c) (i)}

Open Access This article is licensed under a Creative Commons Attribution 4.0 International License, which permits use, sharing, adaptation, distribution and reproduction in any medium or format, as long as you give appropriate credit to the original author(s) and the source, provide a link to the Creative Commons license, and indicate if changes were made. The images or other third party material in this article are included in the article's Creative Commons license, unless indicated otherwise in a credit line to the material. If material is not included in the article's Creative Commons license and your intended use is not permitted by statutory regulation or exceeds the permitted use, you will need to obtain permission directly from the copyright holder. To view a copy of this license, visit http://creativecommons.org/ licenses/by/4.0/.

(C) The Author(s) 2017 